DOC.

D101.146:

A99

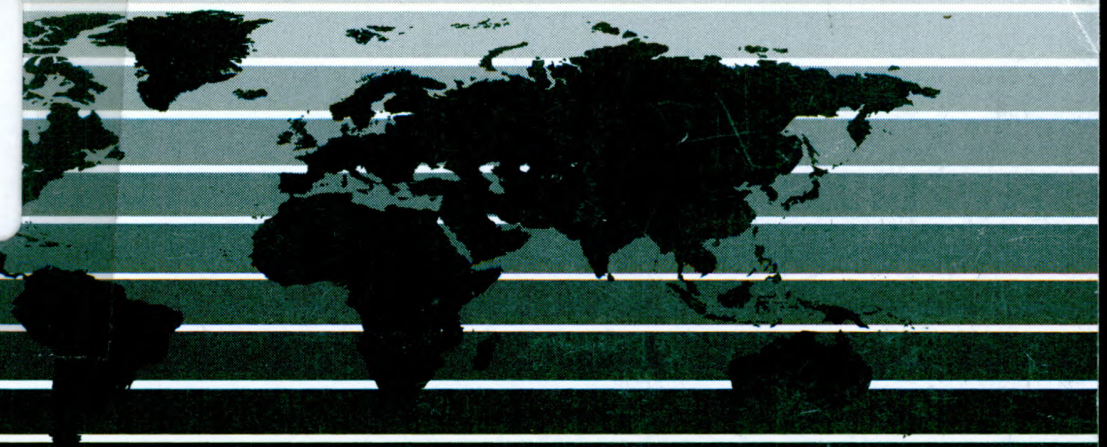

\title{
ere
}

Strategic Studies Institute

Special Report

\section{ASYMMETRY \\ AND U.S. MILITARY STRATEGY: \\ Definition, Background, and Strategic Concepts}

Steven Metz

Douglas V. Johnson II

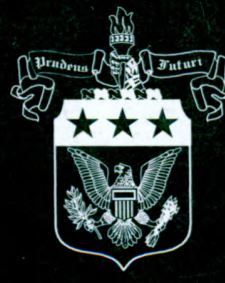

U.S. Army War College 